\title{
SINGING OF CONQUEST? OPERA, HISTORY, AND THE AMBIGUITIES OF EUROPEAN IMPERIALISM
}

\author{
Peter Rietbergen
}

For Joost Langeveld, 'mentor in musica'

Introduction: From Opera as Politics to 'History Opera'

Ever since its 'invention' in the late sixteenth century-at the court of the Medici, in Florence - melodrama, in the original sense of the word, has been a prime vehicle for the representation of power. To put it more bluntly, 'opera' - per musica-often served as a means for political propaganda. Rulers needed to reach the political nation, the elites without whose support they could not function. These elites, who were already well versed in the politics of the day, had to be impressed with the political messages of the governing group. Consequently, throughout the seventeenth and eighteenth centuries, European princes (both religious and secular) rightly perceived and indeed constructed melodrama as a Gesammtkunstwerk: following the baroque ideal of the bel composto, they set out to make it as persuasive a medium as possible for as large an audience as possible-one should not forget that, for example, the Barberini Opera House, in seventheenth-century papal Rome, held some 2,200 spectators.

Since time immemorial, themes taken from history have been used to convey contemporary political messages. So, political opera, too, mostly took its subject matter from the past, whether it was biblical, classical, or in a more narrow sense, European-historical. ${ }^{2}$ To what extent (given the above remark about the size of early modern audiences) this constitutes public access to those pasts per se remains, of course, to be seen.

\footnotetext{
${ }^{1}$ Stanley Sadie, History of Opera (New York: Norton, 1990).

${ }^{2}$ Carl Dahlhaus, 'Die Historie als Oper. Gattungsgeschichte und Werkinterpretation'. Carl Dahlhaus, Vom Musikdrama zur Literaturoper (München: Piper, 1989).
} 
Even within the first two subgenres, the theme of cultural contact and cultural conflict provided both librettists and composers with both dramaturgically and politically exciting possibilities, as can be seen when one analyses, for example, Mozart's La Betullia liberata (1771) or Paccini's Alessandro nell' Indie (1824). However, I propose to concentrate on those operas that pretend to re-create actual moments from European history, more specifically from the history of European overseas relations.

\section{Preliminary Remarks}

Before going into the main questions raised in this essay, three preliminary remarks seem relevant, all related to an analysis of the problem whether free access to the past can, somehow, be considered part of the phenomenon of the history opera.

The critical theorists-not only the Marxist-Socialist analysts in the late nineteenth century but, far more so, the neo-Marxists of the 1960s-who have branded opera as a 'typically' bourgeois phenomenon, somehow linking it to the capitalist economy of Europe's industrial age, only showed they knew little about the history of the genre. While, admittedly, opera was created in and for a courtly context, already in the seventeenth century the bourgeoisie took to it as well. Indeed, though in some parts of Europe aristocratic elites, until the end of the eighteenth century, continued to enjoy their opera in private (that is, in opera houses that did not admit non-nobles), this was not always so. Certainly in the many city republics of EuropeAmsterdam, Bremen, Hamburg, to name but a few-opera was performed in theatres that made no such socio-legal distinctions. But even in France's capital, the royal opera house had its parterre, where both people from the bourgeoisie and the lower classes often clamorously reacted to the performances given, though it often is unclear whether they did so because the music offended them or because the libretto's message was not to their taste-or, indeed, simply because this was a major opportunity to make themselves publicly heard. ${ }^{3}$

3 J. Ravel, The Contested Parterre: Public Theater and French Political Culture, 1680-1791 (Ithaca: Cornell University Press, 1999). 
With the numerical growth of of the European middle class, from the late eighteenth century onwards, and with the cultural changes that accompanied it (for example, the bourgeoisie's wish to emulate aristocratic culture in all its perceived idiosyncracies), attending the opera became a popular pastime ${ }^{4}$-all the more so since attending religious, nonliturgical dramatic music lost ground during the Enlightenment and its revolutionary aftermath. ${ }^{5}$

Moreover, when in the early nineteenth century most private (that is, court and noble) theatres were abolished, the aristocracy, too, had to turn to the new opera houses built to accommodate the ever larger group who wanted and could afford to go there. Consequently, auditoriums, by now certainly more public than ever, became yet bigger, while orchestras, opera troupes, and other performing groups grew in size, too. Even instruments and, perhaps, voices had to increase their pitch to reach the growing audience. Nor, so research suggests, was the audience only growing; since the lower classes increasingly came to the theatre, the bourgeoisie per force had to escape to the opera to keep its high culture-profile. Indeed, all through the nineteenth century both the theatre and the opera remained, by and large, bourgeois, or middle class venues. ${ }^{6}$ Finally, since opera now very much became an economic commodity, its financiers and impressarios ${ }^{7}$ - often entrepreneurs, though they might operate in close contact with urban elites and national governments ${ }^{8}$ - did nothing to discourage this growth, seeking publicity in every way possible to lure as many spectators as possible to the opera house with topics that were certain to seduce them, historical ones being among the most popular.

Inevitably, new performances of (privileged) privacy and enhanced conspicuousness replaced the older, aristocratic-noble rituals. Seating-

${ }^{4}$ Anselm Gerhard, The urbanization of opera: music theatre in Paris in the nineteenth century (Chicago: University of Chicago Press, 2000); B. Emslie, "The domestication of opera'. Cambridge Opera Journal 5.2 (1993), 167-177.

${ }^{5}$ Peter Rietbergen, 'Het Nieuwe Testament verklankt. Muziekdramatische interpretaties als instrumenten van kerstening in negentiende-eeuws Noordwest Europa'. C. Caspers et al. (ed.), Wegen van Kerstening in Europa (Budel: Damon, 2005), 139-154.

${ }^{6} \mathrm{H}$. Gras \& H. van Vliet, 'Paradise lost nor regained: the social composition of theatre audiences in the long nineteenth century'. Journal of Social History 38.2 (2004), 471-512.

7 For example J. Rosselli, The Opera Industry in Italy from Cimarosa to Verdi (Cambridge: Cambridge University Press, 1984).

${ }^{8}$ For example J. Fulcher, The Nation's Image: French grand opera as politics and politicized art (Cambridge: Cambridge University Press, 1987). 
in stalls, boxes, and so on ${ }^{9}$-in the opera house very much became a matter of money, as, for example, in the New York Opera's 'diamond horseshoe', the tier of boxes where tiaras were shown. The auditorium itself became a theatre to show one's status. Indeed, the seeing and being seen, the publicising of the self that always had been part of the opera-going act, became increasingly important, being enacted in ostensibly separate and yet publicly visible social spaces geared to the different classes who attended the opera. ${ }^{10}$

My second remark concerns, inevitably, the perennial question of whether we can gauge the impact of a work of art on its public. Obviously, I would like to know if history opera in any way did influence the audience's sense of past, whether 'the' past or their past(s).

However, for the better part of the history of opera-and, for that matter, of the other performing arts--there are no sources to help us answer this question other than in a largely impressionistic way. If one has contemporary reviews at all-not a common feature of public cultural space before the nineteenth century - these address, in the case of opera, the qualities of the work and its composer, or, more often, of the performers, as well as, even more often, of the staging. It is only seldom that the wider cultural context is analysed and the reception by the public reflected upon. Undeniably, history opera was, certainly since the beginning of the nineteenth century, a very public and, indeed, large-scale cultural phenomenon. But though it used all the emotionally effective means of music and the theatre, thus addressing all the senses, my assumption that, by its very nature, it must have created a historical sensation that may or may not have converged with information about the past conveyed through other channels must remain unproven.

Last, but not least, we should note that in studying history operaindeed, in studying the melodramatic genre as such-a strange phenomenon has occurred. Even nowadays, many musicologists and many more music lovers blightly assume and publicly state it was the composer who determined the message, political or otherwise. Thus, for example, Le Nozze di Figaro often is interpreted as the reflection

9 R. Martorella, 'Occupational specialization and aesthetic change in opera; some historical inquiries'. International review of the aesthetics and sociology of music 10 (1979), 89-98.

${ }^{10}$ For example J. Davis, 'Opera and Absolutism in Restoration Italy, 1815-1860'. The Journal of Interdisciplinary History 36.4 (2006), 569-594, here 547. 
of Mozart's supposed and irrepressible revolutionary love of libertyactually, the interaction between, for example, Mozart and his librettist Da Ponte was a far more complex one. ${ }^{11}$

The general assumption of the composer's predominance obviously stems from the fact that over the past two hundred years the musical part of opera has been extolled to such an extent that composers have achieved cult status, while librettists, if mentioned at all, usually have been blamed for everything a composer was not able to realise. However, this situation was a comparatively new one. Well into the eighteenth century, the writer of the operatic textbook, the libretto, was recorded and applauded, while the composer, often, remained unknown. ${ }^{12}$ Only since, for example, Verdi, Wagner, and Puccini (and, on a wider scale, from the early twentieth century onwards) have composers begun to participate in the writing of the lyrics or even to create their own textbooks altogether. Though nowadays, too, we tend to praise the composer rather than the writer of the lyrics, if we study opera, especially political opera, for the messages it contains, we should concentrate on the libretto and its author.

Consequently, over the past decades a new scholarly subspecialism has arisen. Those readers interested in the secrets of librettology, especially in its structural-hermeneutical tradition, should preferably peruse the pages of the Cambridge Opera Journal. They contain both the high victories gained by intelligent, close-contextual cultural reading and the low depths reached by often ill-judged postmodern overinterpretation.

\section{'History Operas'-Conquest Operas: \\ The Baroque Vicissitudes of Montezuma}

Precisely since opera often was meant to carry a political and hence public message, the choice of topic was important. It would be fascinating to know, on the basis of quantitative research, if-with the

\footnotetext{
11 A. Steptoe, The Mozart-Da Ponte Operas (Oxford: Oxford University Press, 1990).

12 Peter Rietbergen, 'Montezuma gememoreerd. De barokke opera als "machine" voor de overdracht van cultuur en ideeën'. Hans Bots et al. (ed.), Schelmen en Prekers. Genres en cultuuroverdracht in vroeg-modern Europa (Nijmegen, Vantilt, 1999), 191-236.
} 
coming of the Enlightenment at the end of the seventeenth century, and the advent of revolution during the last decades of the eighteenth century-a slow decrease in the popularity of biblical and classical/ mythological themes occurred, and 'true' history became more en vogue.

Moreover, given its ideological potential, one might assume that the theme of conquest would be a preferred vehicle for a political message, whether the opera's patron was a private-public person such as a ruler, or the state-the nation, even-that wanted to influence the audience's cultural-political notions. However, to statistically answer the two above questions is well nigh impossible.

Though the corpus of European operas, from the beginning of the seventeenth to the beginning of the twentieth century, numbers in the hundreds, many of the operas are not easily accessible in modern editions of text and music. ${ }^{13}$ Indeed, far more are forgotten entirely, gathering dust in libraries where their often hand-written scores have been deposited when, after a few moderately succesful presentations, or, indeed, after one disastrously unsuccesful performance, it was decided that they were a commercial or artistic failure, unable to capture the audience's always fickle mood.

Admittedly, the resurgence of 'ancient' music, since the late nineteenth century, as well as, since mid-twentieth century, the economic need for the recording industry to produce a constant stream of new releases have resulted in the rediscovery of many forgotten masterpieces. Yet, the number of works that were actually written and composed is far greater than the number of texts one is able to retrace, let alone consult.

My own research has led me to understand the increasing importance in European politics of Europe's complex relations with the non-European world-especially, of course, those parts of the two Americas that had been conquered and now were governed by Portugal and Spain, and by the British, as well as the world(s) of Asia that, precisely since they largely remained unconquered, fascinated Europeans perhaps even more.

${ }^{13}$ Franz Stieger, Opernlexicon. I. Titelkatalog (Tutzing: Schneider, 1975); Eberhard Thiel, Libretti. Verzeichnis der bis 1800 erschienen Textbücher (Frankfurt am Main: Klostermann, 1970). 
But though baroque opera often was set in non-European worlds, it only rarely tackled the (near-)contemporary history of those worlds and their political importance for Europe. Rather, in most such operas the place where the 'other' lived was presented as different in both space and time and, hence, as unrelated to Europe. ${ }^{14}$

The only major exception to this rule is the group of musical dramas based on the perhaps oldest and certainly most obvious story linking Europe to distant regions-namely, the classical-medieval Alexander romance and its many ramifications. It was, also, the most popular. Indeed, precisely the Macedonian monarch's many travels and adventures, as well as his exciting amourous exploits, provided the subject matter for dozens of Alexander-related operas written during the ancien régime. For example, Pietro Metastasio's retelling of the tale of Alessandro nell'Indie alone created a libretto that inspired no fewer than forty composers between its first publication in the 1720 s and its last setting in the early 1820 s. $^{15}$

Another (albeit much smaller) group that somehow tells of the links between Europe and its 'significant others' consists, of course, of operas dealing with the Crusades of the eleventh and twelfth centuries. However, instead of being used for a political message-beyond, that is, the obvious one of Europe's (that is, Christendom's) wish to regain the Holy Land-the texts of these musical dramas, too, seem rather to reflect Europe's need for exotic, adventurous settings in which to place a tale of romantic love and should certainly not be subjected to ideological-political overinterpretation.

Keeping in mind the above caveat, on my counting, only a handful of pre-nineteenth-century opera texts can be linked to Europe's more recent-that is, since the late 1400 s-contacts with other cultures and their worlds. Basically, these are the five works, written and composed in the late seventeenth and during the eighteenth century, that represent the arrival and vicissitudes of the first discoverer, Columbus, amply dealt with by Maehder. ${ }^{16} \mathrm{~A}$ few more works somehow represent the momentous as well as sensational episode of Hernan Cortez'

\footnotetext{
14 Rietbergen 1999.

${ }_{15}$ Peter Rietbergen, Europe. A Cultural History (London: Routledge, 2006).

16 Jürgen Maehder, 'Mythologizing the Encounter. The representation of the "discovery" on the opera stage'. Carol Robertson (ed.), Musical Repercussions of 1492: Encounters in text and performance (Washington D.C.: The Smithsonian Institute, 1999).
} 
conquest of the empire of the Aztecs in Mexico, culminating in the socalled 'noche triste' of 30 June 1520. It was then that the small band of Spaniards who had first reached the coasts of mainland Middle America the year before toppled the regime of Emperor Montezuma. In many ways, this moment, which I myself have studied in some detail, could be seen as the 'birth' of Latin America-of European colonialism and imperialism. ${ }^{17}$

From the mid-1660s onwards, John Dryden's play The Indian Queen (1664) was set to music by a number of composers-Henry Purcell amongst them-and proved lastingly popular, though it was, from a historical point of view, a largely fictional tale of preconquest Mexico. Its sequel, The Indian Emperour (1665)-equally popular, as the avid music and theatre lover Samuel Pepys tells us in his Diary-did set out to give the story of Spanish imperialism, ending on an appropriately tragic note with Emperor Montezuma's suicide. Yet it does suggest that, in the long run, the Spanish conquistadores and their Aztec subjects learned to live together, which of course represented the version of history preferred by imperial Spain and its historiographers.

Regardless of whether the rumour of the operatic success of this tale spread from London to other European capitals-perhaps by diplomatic channels-it did inspire the Venetian writer Alvise Girolamo Giusti when he wrote a Montezuma libretto that was then set to music by Antonio Vivaldi (only recently rediscovered) for the 1733 Venetian precarnival or, rather, opera season.

In 1765 Antonio Cigna-Santi wrote another Montezuma text, this time for the royal opera at Turin. During the subsequent decades, his treatment of the topic proved popular with a number of composers, including Joseph Haydn, who set it for a performance at the princely palace of Eszterhásza. Both Giusti and Cigna-Santi loosely based themselves on a reading of Antonio de Solis' Historia de la Conquista de Méjico (Madrid, 1684). However, while Giusti ends his interpretation of the conquest story on a conciliatory note-with Montezuma sighing that, with the coming of Spain and Christianity, Mexico will enter a new phase of its history-Cigna-Santi is less ambiguous and at the same time more bloody: he has the emperor bequeath his realm to Cortez in order to revenge himself on his Aztec enemies. This fable did, of course, serve to legitimise the Spanish conquest.

${ }^{17}$ For the following: Rietbergen 1999. 
While variations of this eighteenth-century librettic rendering of the tragedy of sixteenth-century Mexico remained popular well into the early years of the nineteenth century, they do not offer the most interesting interpretation of the story of Montezuma. In Spring 1755, the Prussian king Frederic the Great ordered the text of his own version set to music by his court composer, Carl-Heinrich Graun. Using a number of earlier texts, both literary and historical, the king created a wholly idiosyncratic interpretation of the tragic emperor, presenting him as a monarch who, although nominally pagan, nevertheless practices tolerance and humanity, ruling accordingly; however, he is attacked by a self-confessed Christian, a self-proclaimed civilised being, whose actions nevertheless are basically intolerant, merciless, and indeed inhuman in their cruelty when measured against the universal human values proclaimed by those same Europeans. Thus, Cortez the conqueror epitomises the 'old', unenlightened Europe, which Frederic spent his life to try to combat and change.

Fascinating though it is, Frederic's opera does not seem to have survived its first Berlin performances. It would have been illuminating to know the reactions of the audience who, in Berlin as in Venice-and, it has to be added, in many other European towns as well-were not restricted to the nobility and other sections of the elite, but did indeed include the (upper) bourgeoisie as well. ${ }^{18}$

\section{Changing Views of Conquest?}

The abovementioned argument notwithstanding, it was only from the early nineteenth century that opera became a mass medium. Increasingly, it was precisely the now burgeoning middle class who appropriated the genre as a form of aesthetic, high-brow amusement. ${ }^{19}$ Yet, its ability to adroitly manipulate the sensus politicus was never underestimated by the men who commissioned musical drama. Indeed, opera remained a favourite vector for the transfer of those images of the past that those in power considered necessary to uphold a desired (political, cultural) present. Consequently, like history painting exalted the

${ }_{18}$ Rietbergen 1999.

$19 \mathrm{Ph}$. Ther, In der Mitte der Gesellschaft. Operntheater in Zentraleuropa, 1815-1914 (Vienna: Oldenbourg Verlag, 2006); K. Maase, Grenzenloses Vergnügen. Der Aufstieg der Massenkultur, 1850-1970 (Frankfurt: Fischer, 1997). 
national past, or, as I have argued elsewhere, of a variety of (national) pasts-mostly departing from hodiecentric premises-so did many history-based operas. ${ }^{20}$ Sometimes a painter even realised that his grand-scale evocations of the past would be definitely enhanced by grand-scale music. Thus, in the 1840 s, Wilhelm von Kaulbach, painting his cinemascopic rendering of the 'Fall of Jerusalem'-which in many ways is a conquest picture since it really sets out to represent the triumph of Christianity-decided to compose an oratorium to dramatically enhance the visual effect of his huge canvas.

However, because the nineteenth century was not only the Age of Nationalism but also the Age of (European) Imperialism, it is not surprising that the non-European world and, specifically, imperial history now provided the themes for (grand) opera, too. Nevertheless, I must admit that, perusing the lists of titles available for research, I did discover far fewer of these imperialist operas than I had expected. Nor did the ones I did find follow the patterns outlined by the scholars who have turned European imperial culture into such a thriving industry. For example, despite the suggestive (albeit highly selective) reconstruction of Europe's relations with the Islamic Near East proposed by the late Edward Said, I had to conclude that European music lovers of the nineteenth century were not regaled with dozens of operas that took the one most logical of topics for their subject matter, the Crusades.

For would one not have predicted that the epic struggle for the Holy Land would have been popular with both writers and composers, given the fact that, besides being wars of conquest, they presented endless possibilities for setting contemporary anti-Islamic feelings-as well as contemporary notions about Europe's increasingly political, rather than economic, role in the Near East-in a historical and obviously romantically appealing setting? Admittedly, we have Gioacchino Rossini's Maometto II, reworked as L'Assedio di Corinto (1820-1826). It is set in 1459 but actually celebrates the Greek War of Independence of the early nineteenth century. We have Giacomo Meyerbeer's Il crociato in Egitto (1817/1824) and, of course, Giuseppe Verdi's I Lombardi alla prima crociata, reworked as Jerusalem (1843/1847), which does tell of one muslim's conversion to Christianity. And we have a

${ }^{20}$ Peter Rietbergen, 'Verbeeldingen van het verleden in woord, beeld en spel. Een complex cultureel continuüm voorbij de wetenschappelijke tekst'. Tijdschrift voor Geschiedenis 117.2 (2004), 187-206. 
few others. Yet I feel one can only meaningfully construct a Crusading opera sub-subgenre of the conquest subgenre if one accepts that it contains no more than a dozen works.

Of the conquest subgenre, I propose to analyse three examples, randomly chosen to be evenly spread over the nineteenth century, precisely because they promise to highlight three conquerors whom the audience, if one wants to characterise their cultural context as orientalised in the Saidian sense, were meant to interpret as European heroes. My texts are Gaspare Spontini's Fernand Cortez, ou la conquete du Mexique, first performed in 1809; Giacomo Meyerbeer's L'Africaine, first staged in 1865; and Alberto Franchetti's Cristoforo Colombo, the musical showpiece of Italy's elaborate 1892 Columbus celebrations.

Given the fact that these three operas reflect the traditional practice that prevailed until the end of the nineteenth century, the first question is always, Who wrote the lyrics? Then, of course, one should try to find out what, if any, historical sources they used to portray the relationship between Europe and its other worlds, and how they translated the material into their own chosen medium. Moreover, one needs to analyse the extent to which the laws of the opera libretto dictated the translation, the transformation of historical information. Obviously, it is important to study the people responsible for commissioning these operas-their reasons and the general cultural context in which these pieces were supposed to function. Finally, we need to address the problem of the reception of these pieces, beyond the music, asking how the intended message of the text-or, indeed, of the entire mise-enscène-was actually received by the (various European) audience(s). Rather than systematically and analytically answering these questions, I will present my findings as a running story.

\section{In the Montezuma Tradition?}

In 1808, Gaspare Spontini set his music to a text written by Victor Etienne de Jouy and Joseph Esmenard. ${ }^{21}$ The former was a well-known journalist and writer, the latter Napoleon's official censor of the Parisian

${ }^{21}$ Paolo Fragapane, Spontini (Bologna: Sassone, 1954); Charles Bouvet, Spontini (Paris: Rieder, 1930). 
theatres. The composer was the favourite of France's imperial couple. Indeed, the emperor, obviously believing in music's ability to move the masses, considered him the musician 'best qualified to serve his projects and add lustre to his reign'. ${ }^{22}$ Consequently, the lyricists and the musician cooperated within the overtly political framework that determined all art production during the Bonaparte epoch.

In this case, it seems that none other than Napoleon himself suggested the plot, for which Esmenard then drew the outlines. In 1808, the emperor was planning to invade Spain and hoped that an opera based on the story of the Spanish invasion of Mexico in the 1530s might be used to convey his own political message: as had been the case in early sixteenth-century Mexico, early nineteenth-century Spain, too, was in the throes of the forces of evil (that is, an obscurantist priesthood) and hence should be liberated by the forces of good (that is, of civilisation as brought by the Enlightened French). To flatter the people he wanted to thus save, the Spaniards were given the role of the heroic protagonists in the new opera. Instead of accepting that most operagoers would know that the sixteenth-century Iberian conquistadores had brutally massacred the Mexicans-for three centuries, the leyenda negra had been quite effective in blaming the Spaniards-Jouy and Esmenard fashioned a strange tale clearly meant to accommodate Bonaparte's ideology and policy. This is the more surprising since at least Jouy wanted his text not to be a myth, but rather a real historical epic, as he indicated in his Avant-Propos historique to the 1809 Paris edition of the opera's music and text.

True enough, the work starts from the known facts, with a number of episodes taken from the canonical, although obviously Eurocentric and not always factually correct invasion history. Obviously assuming that historical veracity did matter to convince the audience, Jouy, regardless of costs and logistics, even introduced no fewer than seventeen horses on the stage, arguing that 'they are by no means intended as a mere spectacular effect; their object is to recall the surprise and terror felt by the Mexicans on first seeing them, and the part they played in this memorable enterprise'..$^{23}$

To stress the less-than-civilised state in which the Aztecs live, their first collective appearance is in a danse barbare, during which they

\footnotetext{
22 Bouvet 1930.

${ }^{23}$ Bouvet 1930, 49.
} 
chant that the invaders, a few of whom have been taken captive, should be sacrificed to the gods. In their turn, the Spanish prisoners declare their willingness to die for their country, and thus gain immortal fame. Montezuma is shown vacillating between fear for the invaders, whom he wants to meet, and his high priest's wish that they be immediately put to death.

Singificantly, the tale's heroine, an Aztec princess in love with Cortez, describes him to her emperor as someone who 'd'un Dieu consolateur nous apporte les lois'-a man who 'on behalf of a God of Mercy brings us the Law'-and beseeches him to liberate the prisoners. In other conversations, she stresses the power of the Spanish God, juxtaposing him to the blood-decked idols of her own people. In the end, she concludes that their laws, their many arts, and their God make the Spaniards superior-a typically Enlightened, and also very French, analysis of European culture.

When Cortez appears, dominating the opera's second and third acts, a close reading of the text reveals an interesting point: quite obviously, he is modelled on Napoleon, described in terms that echo the emperor's preferred self-image: he is a leader who, through the power of his words and the strength of his will, convinces his soldiers to follow him wherever he leads them. But of course the ultimate aim is not war, but peace, as Cortez declares: the peace that, in the second act, the choeur des deux nations demands as the basis for a harmonious life: 'D'une paix sans affronts / que ce jour soit le gage, / qu'elle unisse à jamais l'un et l'autre univers' ('Let this day be the reward of a peace without dishonour and forever unite both our worlds'). This was, of course, never the message that the Spaniards held out to the Aztecs, though, admittedly, quite a few Iberian missionaries reasoned in this vein. It was, undoubtedly, very much the ideology Napoleon used to legitimate his conquests. The response, voiced by a choir of Mexican women, is equally what Napoleon so loved to hear: 'Enfans du Dieu de la Lumière qui parmi nous portez vos pas'-('You children of the god of light who now towards us come'). Thus did they welcome the soldiers of Cortez. In their turn, these exclaim that never did the 'bright star of the Enlightenment shine on more beautiful shores'.

After having quelled a rebellion amongst his troops, who tell him they would rather take the Aztec offer of gold and leave than continue their perilous trip to the capital, Cortez/Napoleon gains the upper hand again with promises of fame and honour, claiming, 'cette terre est à moi'-('this land is mine'). 
Montezuma, desperate, decides to commit suicide when Cortez and his men finally reach Tenochtitlán, hearing Cortez/Napoleon exclaim, 'Enfans de la gloire, / ce monde est à vous; / dans sa course infinie, / qui peut arreter le vainqueur? / qui peut résister au génie' ('Children of glory, this world now is yours. Who can halt the genius in his victorious course?'). It is, of course, again Napoleonic rhetoric, rather than anything Spanish.

In the end, entirely contrary to received historical wisdom, Cortez marries his Aztec paramour, and les deux mondes, the worlds of America and Europe, unite in brotherly love, with the former supposedly accepting the civilisation the latter pretended to bring. We should not forget that Napoleon, avidly eyeing Africa and Asia, did indeed have grandiose (albeit totally unrealistic) plans for world domination.

As far as I have been able to reconstruct, the two librettists basically must have reworked the interpretations of the Cortez story that had become popular in musical Europe during the late seventeenth and early eighteenth centuries, as outlined above, preferring, however, the reconciliatory scenario used by Giusti to the bloodier one proffered by Cigna-Santi. However, it has been suggested that Jouy and Esmenard relied on Fernand Cortes, a not very succesful tragedy written by Alexis Piron and first performed in 1744. My reading of the play does not support this attribution. Dedicated to King Philip V of Spain and, according to the author's preface, based on historical fact, the text is, basically, total fiction. It introduces Montezuma as an Enlightened, emphatically anticlerical prince, who battles against the idolatry of his people-suggesting that, rather, King Frederic of Prussia may have read this play and used it for his Montezuma. The Aztec emperor wants to marry the daughter of a Spanish colonial governor but in the end, mortally wounded by his own men, gives her to her true lover, Cortez, admonishing him to bring Christianity to his empire.

Despite his eclectically creative choices from a number of sources, both factual and fictive, Jouy himself seems to have been less than happy with the political restrictions imposed upon him by his commission. He felt he could not very well leave out any reference to the obvious violence perpetrated by the Spaniards against the Aztecs. Yet he did choose to present Cortez and his men as enfans de la gloire when they destroyed the great pyramid of the Aztec capital. Indeed, Huitzilopochtli's temple, presented as the sanctuary of the 'god of evil', and the religious culture it symbolised, marked the Mexicans as barbarians, who had to be forcefully prevented from sacrificing alive the 
Aztec princess who had sided with the conquerors. When in the end the sanctuary is destroyed and Cortez marries the woman-a choice for the traditional happy ending Jouy privately deplored as well-the conquistador claims the new world for himself and for his religion.

Nevertheless, despite the partly unhistorical, politically manipulative end, the audience did not react as the French emperor and his writers had hoped. Quite the opposite happened. ${ }^{24}$ Although presented with spectacular mass scenes set within more than usually sumptuous stage decorations paid for from the imperial coffers-which inaugurated an operatic fashion for decades to come-the Parisian operagoers did not see the arrival of the Spaniards in Mexico as the beginning of liberty, nor did they equate the actions of the sixteenth-century conquistadores with the role propagandistically attributed to the nineteenth-century French forces marching on Madrid. On the contrary, they transferred their sympathy both to the underdog of the past, the Mexican ruler Montezuma and his people, and to the underdog of the present, the people of Spain who now were forced to welcome the French ruler. ${ }^{25}$ Thus, France's persisting revolutionary feelings returned with a vengeance: instead of lauding their own emperor and his soldiers as the bringers of peace and prosperity, the public sided with the victims of imperialism.

However, though the audience did not take to the political message conveyed in the opera's text-indeed, the piece was dropped from the Parisian stage after one season-they did like the music. In his later years, Spontini moved to Prussia. Starting in 1817, he reworked his (by no means ineffective) score no fewer than three times, each time using a revised libretto, thus ensuring the continued musical success of his venture well into the 1830 s.

Not America, or Africa, but Asia

Giacomo Meyerbeer ${ }^{26}$ certainly was not as politically constrained as Spontini and his text writers. In 1837/1838, this hugely prolific and

\footnotetext{
${ }^{24}$ Bouvet 1930, 48.

${ }^{25}$ George Jellinek, 'Fernando Cortez. Gaspare Spontini'. The Opera Quarterly 22.1 (2006), 187-189.

${ }^{26}$ Siegfried Döhring, 'Meyerbeer-Grand opéra als Ideendrama'. Lendemains 31.2 (1983), 11-21.
} 
popular composer started setting to music a text given him by the equally prolific and popular author Eugène Scribe. ${ }^{27}$ Intermittently working on the project, not until 1863 did their collaboration result in L'Africaine, which the composer considered his masterpiece, though he did not live to hear and see it performed.

The title of the work is strangely misleading. The first three acts are set in late fifteenth-century Lisbon. Only the two last acts take the audience abroad, but not to Africa, as they might have expected-and as, indeed, the composer had originally planned. The action now takes place in India, for though Meyerbeer had set out to create an opera situated in Spanish Africa, he changed his mind after reading the famous sixteenth-century epic of Portuguese colonialism Os Lusiadas, by Luis de Camoes. Meyerbeer also was fascinated by the life of Vasco da Gama, who in 1498 had been the first European to reach India by way of the Cape of Good Hope. Consequently, the composer asked the librettist to change the location as well as the plot of the story.

To acquaint himself with the seafaring exploits of the Portuguese and the early history of Lusitanian-Indian contacts, Meyerbeer did consult a number of scholarly studies, both in English and in German. Musically, he retained the tam-tam, originally used, supposedly, to produce some African local colour, but he also introduced the glockenspiel, which may have given the audience some vague reminiscences of Indian temple bells.

Before the opera starts, Da Gama has met and taken captive an Indian princess. On his return to Portugal, he gives her to his fiancée, Dona Inès. How should we interpret the story that follows? If I were a devotee of the orientalism theories of Edward Said, I would argue that Vasco da Gama, representing Europe, discovers India, as represented by Selika. He is enchanted by her-and, consequently, wants to possess her, to conquer her. Yet, on his return to Portugal, he rejects her in favour of his European bride-to-be, who moreover becomes Selika's mistress as Europe became India's master. However, on Vasco's second voyage to the East, it is she, Selika, who saves him from death. Again enchanted and seduced, he now promises to honour and marry her. Still, in the end he does not, but returns to Inès instead. Selika

\footnotetext{
${ }^{27}$ Karin Pendle, Eugène Scribe and French Opera of the Nineteenth Century (Ann Arbor: UMI Press, 1979).
} 
is rejected again and dies by her own hand. With her, symbolically, India's hope of an equal, fruitful relationship with Europe dies, too.

Even if I were a Saidian, I would hesitate to argue that, consciously or subconsciously, a man like Scribe actually did set out to thus translate Europe's colonial history-whether he was introducing his own, coded interpretation or, for that matter, assumed that the audience, consciously or subconsciously, would interpret for itself his text in that way. Indeed, I very much doubt it. ${ }^{28}$

\section{Excursion I: Unequal, Imperial Relations as Unequal, Male-Female Relations?}

However, one may perhaps suggest that the conventionally Romantic operatic theme of the overbearing man and the willing (but sometimes rejected) woman takes on another meaning in such 'oriental' operas as Louis Spohr's Jessonda (1822/1823), Gaetano Donizetti's Dom Sebastien, roi de Portugal (1843), Franz Berwald's Drottningen av Golconda (1863/1864), Leo Delibes' Lakmé (1883), and Giacomo Puccini's Madama Butterfly (1903), most of which are situated in Asia, as is L'Africaine, too. Indeed, one might argue that these operas constitute a smallish sub-subgenre in which the conquest theme is in a way personalised, as well as sentimentalised, reducing any possible wider colonial or imperial connotations to the story of the love between a European male and an Asian female.

Spohr based his Jessonda on a longtime favourite, Antoine Lemierre's play La Veuve du Malabar (Paris 1770), which told its audience about one of the customs they most deplored in India's otherwise fascinating culture: the Hindu habit of suttee, which demanded that a widow follow her dead husband onto the funeral pyre. Spohr's German librettist Eduard Gehe rewrote the tale, setting it in sixteent-century Goa.

Jessonda, the widow of a Rajah, is rescued from her dire fate by a fellow countryman, who, for amorous reasons of his own, has decided to side with her former lover, the Portuguese captain Tristan d'Acunhaa name that, though referring to a historical person, is here used to

${ }^{28}$ Peter Rietbergen, Europa's India. Tussen fascinatie en cultureel imperialisme (Nijmegen: Vantilt, 2007). 
portray an entirely fictitious conquistador. In the end, the two of them liberate Jessonda.

Donizetti considered Dom Sébastien to be the best work he ever composed. It certainly was one of the grandest of the many grand operas he wrote, asking for some impressive (though, in the end, perhaps financially crippling) staging. Using a libretto written by, again, Eugène Scribe, he tackled the complex last days of Portugal's ill-fated last independent indigenous king. The historical Dom Sebastiao was the man who mounted a Crusade against the Moors in Morocco and who in 1578 was killed in the battle of Al-Kasr al-Kebir. Portugal then was annexed by Spain, but for decades legend had it that Sebastian had not after all died, but would return, to once again bring independence to his country. Most of this is discarded in Donizetti's or rather Scribe's opera. The king, in love with a Moorish girl forced to convert to Christianity-actually a not uncommon fate for the many Moors who did live in sixteenth-century Portugal-finally meets his end in Lisbon when, with her help, he tries to escape the intrigues of those Portuguese who, favouring the Spanish cause, want to depose him.

Berwald, Sweden's most famous nineteenth-century composer, is said to himself have written the text of his opera about the queen of Golconda-long famous in Europe as the fabulous diamond- and gold-rich kingdom in southern India. When the work was finished, it was not performed, however, although its overture became a very popular piece. The music could only be heard in its entirety when, on the occasion of Berwald's centenary, in 1968, the royal opera in Stockholm decided to stage it.

I find the opera remarkable mostly because it closely resembles Spohr's Jessonda. And yet it does not. True, in Berwald's piece, too, we find a woman being rescued from death by a man, a French officer, which seems to point to a Gallic source for Berwald's inspiration. But Aline, the queen in question, is only apparently Indian. Actually, she too is French, having reached the far shores of India after a series of bizarre adventures that recall the vicissitudes of the protagonists in yet other European oriental operas like Mozart's Entführung aus dem Serail. Nor did Berwald's libretto reach back to Lemierre's theatre piece only. Indeed, the story of his tale needs to be outlined in some detail, since it is in a way exemplary of the many and intricate links that exist between the store of literary texts available for use as libretti and the music composed for them. 
I discovered that in 1803 a comic opera was composed by Henri Bertan, based on a libretto by Jean-Baptiste Vial and Edmond de Favières, titled Aline, reine de Golconde. The same tale was used by François Boieldieu for an opera he wrote in St Petersburg in 1804. In their turn, they obviously used the extremely popular though highly improbable picaresque prose tale about a French milkmaid who becomes queen of an Indian kingdom, published in 1761-and reprinted in 1803-by the libertine French nobleman/author Stanislas de Boufflers. Incidentally, it had already been turned into an opera-ballet in 1766 , by Pierre Monsigny, and used as a libretto again by the German composer Johann Schulz sometime before 1800 .

Yet, contrary to some of his predecessors, whose work he may or may not have known, Berwald chose to give his tale a mock-tragic note, in highlighting the queen's narrow escape from death at the hands of a jealous husband, before the two protagonists join again in a happy end.

In Delibes' Lakmé-nowadays mostly known for its mellifluous flower duet and its soprano show stopper, the famous bell song 'Où va la jeune Hindoue'-is based on the 1880 novel by the hugely popular French orientalist writer, Pierre Loti. The eponymous heroine, daughter of a Hindu priest, falls in love with a British officer, Gerald, who accidentally enters the sacred precinct where she lives. Her father, enraged at the blasphemy, stabs the trespasser. When the two lovers yet escape, indicating Lakmé's readiness to leave her people and culture for a life in Europe-suggesting its superiority? - it is Gerald's fellow officer Frederic who reminds him that he, a British officer, cannot marry his beloved. Lakmé, realising he will desert her, commits suicide.

Madama Butterfly was first peformed in 1904. Set in 1890s Japan, Puccini and his librettist Luigi Ilica seem to have based the story on the American David Belasco's 1900 play Madam Butterfly, which was largely indebted to John L. Lang's 1898 novella Madame Chrysanthème, which, in its turn, originated in a real-life American-Japanese relationship. Yet, the Puccini opera also suspiciously repeats the basic structure of Lakmé. No wonder, since it definitely refers to another novel by Pierre Loti, who was well known to milk his successes and who, moreover, had lived in Japan and taken a Japanese girl, Okiko-san, as his common-law wife. Now it is an American officer, one Pinkerton, who falls in love with a Japanese geisha, who, to show her love, is 
willing to renounce her faith. After they have married-according to Japanese custom-Pinkerton leaves her with child, promising however to return 'one beautiful day', as Butterfly sings in 'Un bel dì vedremo', perhaps the best-loved aria in this opera.

When he does return, he is married to an American girl, who claims his and Butterfly's significantly blond-haired child. Butterfly hands over her little son to his father, to America-putting the Stars and Stripes in his small hand-and commits suicide. No need to say that the opera, soon performed in a Japan that started thirsting after Western culture and yet, precisely in doing so, wanted to escape Western imperialism, met with no few problems there.

In this imperial context, one may read the libretti of these five operas as ever so many tales of conquest. After all, white, Western men are shown winning the unconditional love of the Eastern heroines. Yet, there are differences between the attitudes represented in the works that compose this small group.

The first two are seemingly oblivious of any European misgivings about interracial and interfaith problems. Whether the need for a happy end (rather than some tragic finale) determined these choices is not clear. We do know, however, that Jouy-who after all was the librettist for Spontini's Cortez-had not dared to conclude his text for Spontini's greatest success, La Vestale, with the Vestal Virgin's death, arguing that while

[h]istoric truth demanded that the guilty Vestal should suffer the death to which her sin exposed her; but was this fearful catastrophe-which might have been introduced by means of a narrative in regular tragedy-of such a nature that it could be consummated before the eyes of the spectator? I do not think so.

The third opera in this selection, Berwald's, only plays with the possibility of an Indian-European opposition/union. In fact, he repeats a ploy used since the Middle Ages in many poems, novels, and hence operas, positing the hero and heroine in two opposite cultures-Islamic and Christian-to finally reveal that the Islamic person is actually European and Christian after all. For centuries, it has been Europe's way to evade having to face the possibility of interracial mingling. Even in the 1990 film epic Dances with Wolves, the heroine, before marrying the white-American hero and bearing his children, turns out to be an equally white girl, long ago captured and raised by the native Indians. 
Indeed, one may read the rejected woman theme that decides the fate of Lakmé and Butterfly and, of course, Meyerbeer's Selika in L'Africaine precisely as a reflection of the growing European fear of the effects of miscegenation, of interbreeding with other races. By the mid-nineteenth century, that 'danger' had become articulated in consequence of the greatly increasing number of such relationships, which worried most colonial governments and certainly Europe's more vociferous Christian elites.

In all three operas, this fear seems to operate despite the fact that the women were, indeed, willing to adopt the culture of their beloved men-they were, if one wants to use jargon, participating in a sacrificial myth that denoted or even sealed the passage from the one culture, presented as inferior, to the other, which deemed itself superior.

All this notwithstanding, I feel that both Scribe's libretto for L'Africaine and the Loti-based ones used by Delibes and Puccini allow the listener to voice a critique, however conventionally Romantic, of precisely the attitude and interpretation outlined above. We do know that contemporary audiences, at least of Puccini's Butterfly, often sided against the European male and with the Oriental female. ${ }^{29}$ The males might have come and conquered, but they hardly behaved like heroes. To me, the obvious, though unanswerable question in this context is, of course, whether a dawning awareness of a changing female perspective of these specifically gendered tales did influence both lyricists and composers to slowly alter their position. After all, women went to the opera almost as much as (their) men, certainly from the second half of the nineteenth century onwards, as is shown by recent Dutch research. ${ }^{30}$ Inevitably, the management of opera houses must have considered their tastes and preferences, too, in accepting or rejecting the works proposed for performance, or in commissioning them in the first place.

\section{Excursion II: Close Reading 'Jessonda'}

Though on first view not concerned with conquest, the libretto of Jessonda nevertheless addresses a number of issues that help to further

\footnotetext{
29 William Ashbrook, The Operas of Puccini (London: Cassel, 1969), 101, 116, 117.

${ }^{30}$ Gras \& van Vliet 2004.
} 
highlight the theme of my essay, although I am again the first to warn against overinterpretation.

Thus, one might ask whether one is right in assuming that Spohr's librettist, Gehe, basically meant to oppose a civilised, Christian Europe to a pagan, barbarous India. The custom of suttee is condemned and with it the Brahmins, the priest caste who uphold it as part of their policy to retain power over the populace. Nadori, the monk who loves Jessonda's sister and, in order to make her his, is willing to break his vows and collaborate with the Portuguese, voices his criticism in a cleverly constructed aside to his conversation with Dandau, the high priest, who orders him to inform Jessonda of her fate on the pyre, while at the same time admonishing him to suppress his own sexual urge:

(D/N) Den Trieb der Erde zu bekriegen, mit Geisseln schlage deinen Brust / mit Geisseln schlag' ich meine Brust. Erliegt der Leib, der Geist wird siegen, durch Schmerz verklärt zu Himmelslust.

(D) Geh'denn, des Todes heil'ger Schauer begleite, Priester, deinen Schritt.

(N) (Gleich Schatten zieh'n die stumme Trauer der Schrecken und der Wahnsinn mit.)

(D) Sobald der Todesbot' erschienen schnell stürzt das Leben in das Grab.

(N) (Ich hör'es, seh, es mäh'n Brahminen der Erde Blumen lächelnd ab.)

(D) Wir schleudern aus dem Schoss der Nächte in uns'rer Macht, zu unserm Ruhm, Fluch oder Segen auf Geschlechte; es blüh', es herrsch' das Priesterthum.

(N) Sie schleudern aus dem Schoss der Nächte in ihrer Macht, zu ihrem Ruhm, Fluch oder Segen auf Geschlechte; es blüht, es herrscht das Priesterthum.

Summarising the text, one sees that Gehe presents the Brahmins as the protoypes of clerical obscurantist power and, moreover, as a priesthood that is hostile to sex-thus allowing, albeit indirectly, the audience to reflect on situations still prevailing in their own Christian world, too. Moreover, Nadori remembers: 'In des Tempels öde Hallen / Festgebannt mit Seel' und Leib, / Könnt' ich nur Gebete lallen' ('with 
body and soul chain'd within this temple's sterile halls, I mindlessly did pray'). Thus, in a few words, Gehe manages to present a new, Romantic view of Christianity that condemned not only empty spiritual servitude but empty ritual as well.

Meanwhile, I wonder whether it was a conscious choice on the librettist's part when he has Nadori argue that it is the voice of humanity-rather than of the Christian god-that admonishes him to save Jessonda? Yet, Jessonda's sister does see the Europeans as different and, implicitly, more humane. For as they near the city, 'Den sanftern Gott verkündend'-('Singing the praises of a more merciful God'), they 'Erklären... der Frauen Opfertod für Frevel' ('They state that this form of female sacrifice is an abomination').

The sentiment attributed here to a representative of the native, tobe-conquered people is, though not directly, linked to the ethics of conquest as interpreted by the Portuguese themselves. They declare that those who die in war will be hailed as heroes by their compatriots. Tristan, entering into the particulars, argues that the Portuguese, after they first arrived in India, settled peacefully there on the basis of treaties-which, in a sense, was not historically untrue. Since then, he tells his men and the opera audience, they have been treacherously killed by the natives and therefore are now at liberty to regain with arms what was taken from them. He exclaims, 'Und herrlich weh'n die Fahnen unsers Glaubens. / Verreint denn mit der Kraft die Milde, / denn auch im Krieg lässt sich der Friede üben. / Mitt Gott für unsern König!' ('The banners of our faith do wonderfully wave. With force, now mercy joins, for in war, too, peace always should be sought. With God we now go forth, to battle for our king').

Nevertheless, Tristan confesses that his wandering and warlike existence only became blessed with peace when he learnt to love Jessonda: a sentiment that of course prefectly expressed Europe's early nineteenthcentury Romantic notions about the restraining and civilising effect of womanhood. Indeed, it was a notion that, from the second half of the century onwards, induced metropolitan governments to propagate the migration of European women to their peripheral provinces.

But then again, to free Jessonda from 'Barbarenhänden', as Nadori has described her situation, Tristan does feel that violent action is necessary: 'Auf, zu den Waffen! / Nun schlägt die Stunde, / wo jene Götzenbilder stürzen, / und glanzvoll über ihre Trümmer / der Glaube siegend wandelt' ('To arms, then, for the hour has come when all those idols be destroyed and faith will rule victorious o'er their ruins'). 
Watching the tumultuous scene that follows, any European operagoer who had read the increasingly detailed and scholarly informed literature about Indian religion must have realised that Gehe's descriptions and interpretations were, to say the least, ambiguous, although they made for spectacular staging. In the end, the idol is torn down. Yet, when Jessonda knows she will be spared, the librettist does not have her thank the Christian God. Rather, she praises love as the supreme liberating force-another topos that Gehe must have taken from Enlightened and Romantic rhetoric. The Portuguese, however, having the last word, sing, 'Bekämpft, gestürzt das Götzenthum, / dem Gott der Schlachten Preis und Ruhm!' ('Idolatry has been destroyed, so now let's praise the god of war').

In short, the messages that contemporary listeners may have read or heard in Gehe's text must have been mixed, representing, I feel, the equally mixed feelings about, and the historical-scientific representations of both European and non-European cultures, as well as the relations between them, that came to characterise public debate in nineteenth-century Europe.

\section{Back to 'L'Africaine': Conquest or Critique of Conquest?}

On the evidence of some of Scribe's lyrics, one might present yet another interpretation of L'Africaine. On the one hand, Da Gama has an almost metaphysical sense of mission, transcending the vulgar lust for power and profit usually associated with European imperialism. On the other hand, as if to counterbalance his ideal, the second male hero of the opera, the Indian Nelusko, is represented as the saviour of his people: opposing Vasco's grand vision of empire, he succesfully fights for his nation's freedom - a very nineteenth-century notion, too, albeit one that was applied to European peoples, first, and only long afterwards to the non-European subjects of Europe's imperialism.

We do not know the reactions of the audience that was given Scribe's text and Meyerbeer's music in 1863. The production in the Paris opera was grandiose: it even used a revolving stage, where ships could pass one another. But did the operagoers actually hear and perceive beyond what was, if superficially viewed and interpreted, a simple Romantic tale? For though it was set in exotic surroundings and though the text may lead one to speculate about deeper layers of meaning, in the end it did boil down to a man vacillating between two loves and, finally, 
doing his duty by the woman he had promised to marry. Or should one argue that, rather than stressing, for example, moral imperatives, nonaristocratic birth, or a similar European issue as the major motive for Vasco's choice, it is race that determines it in this European-nonEuropean context?

\section{The First Conqueror}

Of course, amongst those who paved the way for Europe's world wide dominance, Cristoforo Colon takes pride of place, whether we believe he hailed from Genua or Lisbon. Not surprisingly, he has been the protagonist of a great, indeed a surprisingly great number of texts set to music-of operas as well as secular oratorios and of cantatas with one or more vocal soloists. ${ }^{31}$ Taking all these manifestations of more or less scenic-dramatic music together, in eighteenth-century Europe five different productions can be counted, as well as, between 1794 and 1800 , three in the young United States. From 1800 onwards, until the four hundredth anniversary of 'the discovery' in 1892, I count no fewer than twenty-five productions, of which at least nine-the operatic ones-used a text by that prolific writer of lyrics, Felice Romani, who first produced his version of a Columbus libretto in 1828 .

Inevitably, 1892 did show an outburst of conquest singing. In New York, a contest for a prize composition resulted in a cantata written by a German musician that, or so it was announced, would be performed by four soloists, some one hundred instrumentalists, and no fewer than one thousand male singers 'from the leading societies' - an indication of the very public, mass-oriented nature of contemporary music and, consequently perhaps, the reach of its messages. Both in Europe and in the Americas, eight more operas and cantatas were produced.

Meanwhile, in the early 1890s, the name of Alberto Franchetti had been suggested to the organisers of Italy's Columbus manifestations by none other than the grand old man of Italian melodrama, Giuseppe Verdi, who himself politely declined the city of Genua's commission to write an opera for the festivities. ${ }^{32}$

${ }^{31}$ Thomas Heck, 'Towards a bibliography of operas on Columbus: a quincentennial checklist'. Music Library Association Notes 49.2 (1992), 474-497.

${ }^{32}$ Luca Zoppelli, 'The Twilight of the True Gods: Cristoforo Colombo, I Medici and the Construction of Italian Style'. Cambridge Opera Journal 8.3 (1996), 251-269. 
The young composer was given a libretto by the well-known writer Luigi Ilica, who, it has to be said, without acknowledging it seems to have used material from Romani's Colombo. To judge by the original four-act text, Ilica tried to combine a number of elements.

On the one hand, there is Isabella, the Spanish queen who supports Columbus precisely because she has an ecstatic vision of the world, of a New World:

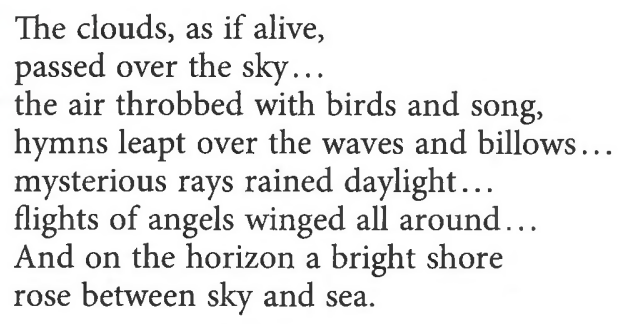

The seafarer, Columbus, on the other hand, is presented as dreaming of discovering facts, of verifying ideas-for example, about reaching Asia via the Atlantic Ocean. It is not clear whether, for reasons of personal gain and glory, he just feigns to join in Queen Isabella's dream-of countless of pagan people redeemed by Christianity-or whether he, too, believes the old religion will rescue new worlds and their inhabitants.

While at sea on his way thither, the compass and the stars seem to present facts that cannot be easily interpreted. He sings, 'So have I been dreaming? / And were you lying, o my thoughts? / And is what seemed a fact to me, / or need of a fact, / no more than a mirage?' Once the Genoese has arrived on the shores of his dreams, following the operatic law that dictated that every hero has his heroine, he falls in love with an Indian queen-as if Ilica wanted to mix the Cortez story with the Columbus one.

Somewhat contrary to all this partly fanciful representation of the past, both the writer and the composer yet wanted to present Columbus against his historical background, using the obviously biased early sixteenth-century Historia de las Indias of Bartolomé de las Casas. To it, Ilica added his own biases. The harsh treatment meted out by the gold-thirsty Spaniards to the Indians with which the opera opens is largely attributed to the servants of the Iberian church-a reflection of young Italy's strong anticlericalism that may have combined with a growing susceptibility for the lot of America's native peoples. However, since the new nation needed the support of the papacy, Ilica 
and Franchetti (an assimiliated Jew) moderated their criticism of the Christian priesthood in the second version, which they produced in 1895, almost immediately after the first performances in Genoa and Milan had proven that the opera was, if anything, far too long.

In subsequent rewritings produced in 1923 and 1936, other elements were lost as well. Thus, the love interest that quite unhistorically had been attached to Columbus was discarded. Now, his faithful friend Guevara falls for the Indian princess Iguamota, who adores him-'You are like God who descends from heaven for me', which almost seems to echo Selika, the heroine from L'Africaine-and she saves him from a plot against the Spaniards. Putting duty above passion-undiluted European-ness above miscegenation?-Guevara yet leaves her, thus repeating the pattern characteristic of all these operas.

The most important change concerned, perhaps, Ilica's and Franchetti's original finale, contained in the last two acts. These showed Columbus' dream to create a New World of justice, of tolerance: the dream not of a sixteenth-century Spaniard, but of a true, Italian, nineteenthcentury liberal hero. He sings, in my translation from the Italian,

Justice returns to the land, and a sense of pity conquers every heart.

No more hate, no more war, no war over race and colour.

Over the entire human family, who were strangers to one another, the God of peace now rules, the God, the God of love now rules.

For whatever reason, the last act was deleted, and with it the rationale of the protagonist's great effort. What remained was a truncated, dramatically incoherent text in which, contrary to historical truth, the hero is arrested and finally dies, disappointed in his hopes-without further reference to the fate of the historical Indians but for a single line: 'The ground is soaked in blood! / The new shore is furrowed with blood'. Unmistakeably, however, even the remaining (almost thirtyminute-long) epilogue sung by Columbus is impressive.

It is a pity that the text was maltreated as much as it was since Franchetti's music, which owes to such other composers as Giordano, Ponchielli, and of course Wagner, is yet original, innovative, and captivating, especially in the way it succeeds in making the individual voices merge with the symphonic-orchestral flow, thus creating unity throughout the work. 


\section{Opera as History, or Opera as Politics?}

Inevitably, I will have to return to a question I asked in the opening paragraphs of this essay. Can we expect history opera-opera pretending to be, at least partly, true to a historical theme and the facts associated with it - to transmit scholarly knowledge, a consensual representation of the past? Well, perhaps we can. It obviously was the pretension of many a librettist, as shown by the example of Jouy, cited above. Yet, just as films set in the past often tell us more about the present of their makers than about the period portrayed, so do history operas-certainly the ones presented above.

In the musical dramas I have analysed, the historical context-taken from Europe's contacts and conflicts with the non-European world since the late fifteenth century-is, quite evidently, an allegory of the European present in which the text and the music were conceived. Surprisingly, however, by and large only few authors did exploit this context to extol colonial or imperial visions as conceived in that present. Nor did they interpret 'the otherness' of the non-European peoples involved from any overt-or even covert-one-sided perspective of European cultural superiority. Indeed, a perspective that questions such ideas often seems a possibility implied in the text. And, finally, even the racial elements that some might be inclined to read into parts of the texts are, I feel, subtexts only-if that.

What the majority of these operas set out to do is, perhaps, embody conflicts of ideas-but basically these are nineteenth-century ideas, not plausibly transferable to the historical period represented. Indeed, they are ideas that reflect contemporary notions. Though set in exotic, nonEuropean worlds, and though taking their plot from events for which European historical sources existed, the politics that emerge from a closer reading of the libretti often are nothing if not messages about the European culture and politics of the day. Moreover, they basically are aimed at a contemporary European audience.

The failed message of Esmenard and Jouy targeted Napoleonic France and its imperial stance that posed as a policy of liberty. And if my interpretation is correct, Scribe and Meyerbeer, writing within the context of post-1848 European culture, seem to extend that libertarian message even to non-European peoples.

As to the Ilica-Franchetti opera, the case is rather more complicated, since the text was altered not one but several times, to such an extent that the original message, or messages, did change almost beyond 
recognition. Yet I feel that, despite the musical references to American-Indian culture-modal writing and ostinato rhythms amongst them-and despite what I have just said about the message contained in the texts that later were deleted, the opera never really was about the discovery of the New World and its consequences. It always was, I think, about the tragedy of a man's dreams being unfulfilled.

But to have Columbus dream of an all-human society in the fifteenth century was, to a mostly educated late nineteenth-century audience, clearly an anachronism. In act two of the opera, the real message transpires, as it becomes evident that Columbus dreams of a society that can be improved by science and all that modernity can offer. So, the opera must have been about the dreams of its late nineteenthcentury, liberal Italian listeners--or, at least, of that part of them with whom Franchetti and Ilica liked to share their own vision of the ways to create a better world.

In short, like so many historical novels, and so much of history painting-two nineteenth-century cultural genres increasingly used to somehow influence visions of and perspectives on pasts European and non-European-history opera, including conquest opera, seems to mainly present past contexts for present-day ideas. In short, history opera, too, offered its audience not access to 'the' past as it was reconstructed by historians, but to 'a' past that recreated a specific vision of the present. 